
University of California Press Berkeley and Los Angeles 1951 


\section{MANUAL DF}

AMERICAN

ENGLISH

PRONUNCIATION

for adult

foreign students

by

Clifford H. Prator, Jr. 
University of California Press Berkeley and Los Angeles California Cambridge University Press London, England

Copyright, 1951, by The Regents of the University of California Printed by Of fset in the United States of America Second Printing, 1953 